http://kitaibelia.unideb.hu/

ISSN 2064-4507 (Online) • ISSN 1219-9672 (Print)

(C) 2017, Department of Botany, University of Debrecen, Hungary

22 (1): 35-46.; 2017

DOI: $10.17542 /$ kit.22.35

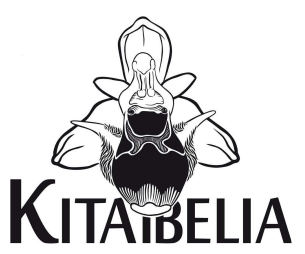

\title{
Felföldy Lajos és a vízminőség-védelemben vele töltött néhány év
}

\author{
CSÁNYI Béla \\ MTA Ökológiai Kutatóközpont Duna-kutató Intézet, H-1113 Budapest, Karolina út 29.
}

Munkakapcsolatunk látszólag igen rövid ideig tartott. Az ő 15 éves, vízügynél befutott pályája és az én vele egy munkahelyen töltött három évem (csak 1977 októbere és 1980 szeptembere között dolgoztunk együtt) nevetségesen csekély idő-átfedés. Ennek ellenére - pláne mai szemmel nézve - ez igen-igen speciális időszak volt, amikor még kézzel írtuk a jelentéseinket, valamint írógéppel, megfelelő határozókönyvek híján, számítógép nélkül dolgoztunk, nekem tereptapasztalataim még egyáltalán nem voltak, vizeink élővilágát csekély módon ismertem csak, s a környezetszennyezés durvábbnál durvább eseteivel sem igen találkoztam. Egy mérnöki szemlélet által uralt kutatóintézeti közegben kezdtem a munkát, a hazai vizek átfogó feltárásáról még nem esett sok szó, és meg lehet említeni - az akkori KGST-kapcsolatok ellenére - a bizonyos fokú nemzetközi elszigeteltségünket is. Felföldy Lajossal ekkor találkozhattam és dolgozhattam együtt. Ő volt az a kutató, akitől kollegáimmal elsajátíthattuk a hidrobiológiai szemléletmódot, a környezet- és természetvédelem szeretetét és ápolását, a magas fokú szakmaiságot.

Lajos bátyám - kollégájával, Tóth Lászlóval együtt - 1965. november 1-én került Tihanyból a Vízgazdálkodási Tudományos Kutatóintézetbe (VITUKI). Az akkori főigazgató - a szintén 2016-ban eltávozott dr. Stelczer Károly - vette őket oda, mint egy, a vízügy által biztosított olyan menedékhelyre, ahol rajtuk kívül másoknak is (például arisztokrata származásúaknak) sikerült munkába temetkezve jótékony homályba burkolózniuk a politikai rendszer kutakodásai, vegzálásai elől. Lajos bátyámnak szókimondásával, egyenes jellemével és keménységével ekkorra ugyanis már antagonisztikus ellentétei támadtak a tihanyi Intézet vezetőségével, ezen keresztül tulajdonképpen a Magyar Tudományos Akadémia vezetőivel szemben. Tihanyból például 56 tájékán vitte el az ÁVO Veszprémbe, ahol elmondása szerint keményen megverték borozgatás közben énekelt, a rendszerre nézve dehonesztáló nótáiért. A VITUKI-ban tehát csupán 15 évet - de micsoda 15 évet! - tölthetett, de ezen idő alatt számos alapvető művel alapozhatta meg a magyar vízminőség-védelmi szakmát és ezzel együtt a hazai hidrobiológia kutatásokat.

1977. október 1-étől dolgozunk tehát együtt a VITUKI-ban 1980 szeptemberéig, amikor is egy évre Hollandiába mentem. A következő évre azonban két alapvető változással szembesültem az előző évi helyzethez képest: a hidrobiológus kutatók a B. épületből (III. Vízminőség-védelmi Intézetből) átkerültek az általunk „Akváriumház” névre keresztelt Halas Laboratóriumba, Lajos bácsi pedig addigra már sajnos nyugdíjba ment. Ennek történetét azonban kissé részletesebben kell később ismertetni, hiszen az eset - a korszak jellemzőjeként - szorosan összefüggött a Velencei-tóval kapcsolatos korabeli történésekkel.

Lajos bátyám és Tóth Laci Tihanyban hosszú időn át dolgoztak együtt, a VITUKI-ban is a tudományos rendezvényeken is minden alkalommal a Felföldy-Tóth kettősként szerepeltek. 
Először még egyetemi hallgatóként találkoztam Velük, amikor első alkalommal voltam a tihanyi Hidrobiológus Napokon. Egy sudár termetű, szigorú tekintetű úr ült az előadóterem legelső sorának jobb széle felé, elegáns nemtörődömséggel hátradőlve, egyik lábát hanyagul átvetve a másikon. Korábban soha nem láttam őt, pedig első pillantásra is jól meg tudta jegyezni az arcát az ember. Mellette egy alacsonyabb és testesebb, de ugyancsak kellő magabiztosságot sugárzó, kreol arcbőrű férfi foglalt helyet. Akkor még csak nem is sejtettem, hogy hamarosan közvetlen kollégák leszünk. Az előadó szerényen beszélt valamiről és rosszat talált mondani. Lajos bátyám azonnal, jól hallható dörmögéssel beszól: -Marhaság. - a mellette ülő úr helyeselt a maga szintén dörmögő hangján.

-Mi történik itt? - tettem fel magamban a kérdést és megfogadtam, én soha sem fogok felmerészkedni arra az előadói pulpitusra, ahol nyilvánosan így ócsárolhatják az embert. Az évek során aztán számtalanszor tanúja lehettem ennek a nyers szókimondásának, amely azonban korántsem volt „véres”. Viszont közvetlen, egyenes, kendőzetlen. És ami a legfontosabb: igaz. Tanulságul szolgáló.

\section{Színészi és írói/költői vénája}

Személyes emlékem az, amikor életem első, kézzel írt témajelentés-fejezetét adtam oda neki átolvasásra, kritikára. Amit visszaadott, az telis-teli volt írva piros golyóstoll-javításokkal, hogy jobban lássam a javaslatait. Kezdeti rosszallásom (bevallom, így volt) ellenére végül igencsak elcsodálkoztam, hogy mennyire igaza volt az Öregnek. Mindannyiunk írási stílusán rengeteget tudott segíteni, javítani.

Beszélt arról is, hogy érettségi előtt pályaválasztási problémája volt, nem tudta, hogy színész legyen, vagy botanikus. Az nagyon jó, hogy végül a botanikus pályát választotta, ugyanakkor biztos, hogy színésznek is kiváló lett volna.

Nagyon sokat és hatékonyan tanulhattunk Tőle az élő beszéddel kapcsolatban is. Mint minden retorikát jól elsajátító embert, őt is kifejezetten jó volt hallgatni. Amit mondott, annak volt eleje, közepe és vége egyaránt. Lenyűgöző nyelvezettel beszélt, nagyon sokszor odavágó irodalmi idézetekkel színesítette előadásait.

Írni is tudott. Micsoda verseket! Lajos bátyám vérbeli költőként néha olyan gyönyörűséggel idézte fel - persze fejből - elképesztő fordulatokkal megfogalmazott szerelmes/erotikus költeményeit egy-egy késő délután, amikor szobájából átjött hozzánk a Laborba, az ilyenkor szokásos teáját elkészíteni, hogy azt hihettük: egy színielőadáson ülünk éppen... Ki is használtuk ezeket a várva várt pillanatokat, hogy minél tovább legyünk együtt és hallhassuk Ôt. Nem kellett őt sokat unszolni, hamar elkezdte felidézni a régmúlt eseményeit, leginkább Tihanyt, s nem ritkán Soó Rezsővel kapcsolatos élményeit. Kitűnő korrajzot lehetett volna összeállítani azokból a történeteiből is, amelyek a rendszer pöffeszkedő hatalmasságairól, azok agyalágyult megnyilvánulásairól szóltak.

Dolánszky Feri mesélte el nekem a következő Lajos bácsitól hallott történeteket:

Sokat mesélt a Tihanyban töltött időkről és az ott történtekről. Miután nagyon szerette (és tisztelte) a műszereket, nem kinevezett, de elismert műszerfelelős lett. Nyilvántartotta a műszerparkot, intézte a kötelező és meghibásodás miatti szervizeket, a kisebb javításokat Ő végezte. Egyik alkalommal egy hordozható $\mathrm{pH}$ mérőt hozott rendbe, előtte az asztalon az üres doboz, mellette a „battéria” és az elektród-pár, amikor megjelent az Akadémiáról „két emberszabású lény", közölték, hogy az Intézet műszereit jöttek ellenőrizni.

„- Tessék parancsolni, itt van a műszerkönyv, a műszerek a folyosón lévő szekrényekben vannak, itt vannak hozzá a kulcsok és a műszerek mellett a megjegyzés, ha az éppen használatban van, hogy kinél, melyik szobában található. 
- Nem, kérem maga mutassa meg, hogy melyik melyik.

- Miért, talán nem ismerik a műszereket?

- De igen, de maga mutassa meg.

- Jó, kezdjük - mondtam nagyon udvariasan. Az egyik elkezdte olvasni:

- Pulfrich fotométer.

- Itt van - mutattam rá a pH mérő üres dobozára.

- Rendben - mondta az ellenőr és kipipálta. - Következő: Zeiss féle lángfotométer.

- Ez nagyon érdekes, mert úgy néz ki, mint egy battéria - rámutattam, kipipálták.

- HP-40 konduktométer. - Rámutattam az elektród-párra, kipipálták.

- Precíziós mérleg. - Rámutattam a battériára.

- Erre az előbb azt mondta - és megnézte a könyvet -, hogy Zeiss féle lángfotométer.

- Nem, azt erre mondtam - mutattam rá a pH mérő üres dobozára. Ekkor már rájöttek és fenyegetődztek, hogy fegyelmit fogok kapni ezért.

- Állok elébe, de figyelmeztetem, hogy a fegyelmi tárgyaláson a sok ember előtt felmutatok egy műszert és megkérdezem, hogy ez mi, nem tudják megmondani, ez tökéletes bizonyítéka lesz annak, hogy azt csinálják, amihez nem értenek.

Elrohantak a moszkovita igazgatóhoz, Salánkihoz, bepanaszoltak, aki összehívott egy álértekezletet és amíg az tartott, valaki megmutatta nekik, hogy melyik műszer micsoda."

Salánkiról még annyit mondott, hogy amikor kromoszóma számlálással foglalkozott, az megkérdezte Tőle: - Biztos, hogy ezek a sejtben vannak és nem a fixáláskor keletkeztek?

Így mesélte: „- Az Akadémia illetékeseinek tudomására jutott, hogy a kutatókhoz nem méltó bohém életet élek. Való igaz, volt egy jó ismerős nagynevű pincetulajdonos, oda jártunk borozni, gyakran vacsorázni, fantasztikus ételeket készítettek. Volt arra is példa, hogy hajnalig ültünk a Balaton partján és népdalokat énekeltünk, de például csak olyat, amiben bármely formában ez a szó, hogy rózsa szerepelt. Háromtagú bizottság jött ezt kivizsgálni, egy nő és két férfi. Koradélután megérkeztek, mondtam nekik, hogy most már ne hivataloskodjunk, arra holnap lesz idő, meghívom önöket egy jó vacsorára, amit elfogadtak. Jellemző, hogy a leendő fegyelmi bizottság elfogadta a leendő fegyelmit kapónak a meghívását. Elmentek ebbe a pincébe, nagyszerű volt a vacsora és a hozzá fogyasztott bor. Utána már az éjszakában lesétáltunk a tihanyi mólóra, a nőt le kellett választani, amit egy kollégám megtett és a két férfi belepisilt a viharágyúba. Másnap reggel sötét öltönyt vettem fel, nyakkendőt kötöttem és mentem volna a tárgyalásra, de portás közölte, hogy a „három vendég” a hajnali buszszal elutazott. Nekik volt igazuk, mert ha lett volna fegyelmi tárgyalás, ott megkérdeztem volna, hogy hármunk közül ketten belepisiltek éjjel a mólón a viharágyúba, én nem, akkor kik voltak?"

„Ugyancsak az Akadémia illetékeseinek tudomására jutott, hogy a kutatókhoz nem méltó öltözékben, például fürdőnadrágban mutatkozok időnként, ezt kivizsgálni az MTA Személyzeti osztályának vezetője, Gujdi Barna elvtárs jött le, fekete öltönyben, nyakkendővel. A laborban elmondta nekem, hogy miért jött. - Természetesen beszéljük ezt meg, de csak egy kis idő múlva, mert nekem az üvegházban időre le kell fejtenem az algatenyészetet, menjünk együtt - mondtam, és elmentünk az üvegházba, ahol azonnal levetettem a köpenyemet és fürdőnadrágban dolgoztam, rendkívül alaposan. Addig Gujdi elvtárs ott ült egy széken a kellemes melegben és a megfelelő páratartalomban. Megvártam, amíg a zakóján több helyen is lehetett látni, hogy átizzadt, akkor befejeztem, együtt lementünk a partra, én beugrottam a vízbe, majd odaültem mellé és mondtam, hogy akkor tárgyaljuk meg a problémát. Nem mondott semmit, elbúcsúzott és elment." 
Nem egyszer mesélt egykori szerelmeiről, kalandjairól a legeslegemberibb módon, bizonyítván, hogy egykori pajzánságuk messze izgalmasabb lehetett bármely későbbi, ún. modern kori pornográfiánál. Persze ezekhez a kalandokhoz emberek is kellettek. Egyszer, évtizedekkel később rákérdeztem: - Nem lehetne közkinccsé tenni ezeket a szerelmes költeményeket, Lajos bátyám? Méltatlankodva reagált felvetésemre: - Mit képzelsz? Ezek olyan személyes dolgok, amelyek senki másra nem tartoznak! Nagyon sajnáltam a dolgot, de teljes mértékben igazat kellet neki adnom: prűd soha nem volt, de szemérmes igen, s röstellte volna kiadni az egykori nőket. Nem tartotta volna illendőnek. Úri ember viselkedik így. Költeményei így elmentek vele együtt, örökre...

\section{A vízügyes hidrobiológus csapat}

A VITUKI-ba kerülésemkor e mérnöki szemlélet által vezényelt kutatóintézetben jó néhány biológus dolgozott már. E biológusok általában mikroszkopizáltak, plankton-vizsgálatokat végeztek, vagy olyan apró méretű állatokat vizsgáltak, amelyek nekem, aki halasként kerültem oda, jobbára még ismeretlenek voltak. Így kollégaként dolgozhattam Bartha Zsuzsa algológussal, aki férjével, a szintén algológus, Hortobágyi-tanítvány Hajdú Lajossal a nyolcvanas évek elején Svédországba disszidált. Gulyás Pali volt a zooplankton szakértője, s Zsuzsával együtt számos dologra megtanított a mikroméretű szervezetekkel kapcsolatban. Patakiné Vásárhelyi Réka kutatta a vízi makrogerincteleneket ez idő tájt. No, ettől a munkától idegenkedtem a legjobban, nevezetesen a minták cukor-oldatos úszatásától, amikor egy tömény cukor-oldatban kialakított fajsúly-különbség segítségével kellett szétválogatni a vízi szervezeteket az egyéb hordalék-részecskéktől. Ennél unalmasabbat el sem tudtam volna képzelni a magam akkori fiatal fejével.

Nem sokkal korábban ment el ebből a csapatból az OVH-ba adminisztratív munkakörbe Bíró Kálmán, akiből végül is ez idő tájt Felföldy Lajos passzírozta ki erőteljes fellépésével az európai-hírűvé vált Chironomida-határozóját. Ez volt tehát a VITUKI akkori biológus-csapata, ahová - nem tervezett módon, tehát véletlenül - sikerült bekerülnöm.

Nem sokkal korábban kezdődött meg ugyanis annak a laboratóriumnak a tervezése, amelyben majd a még építés alatt álló Paksi Atomerőmű hőszennyezésével kapcsolatos kísérleteket kellett volna végezni. A munka vezetésével természetesen Felföldy Lajost akarták megbízni. Lajos bátyám e téren már hatalmas tapasztalatokra tett szert, hiszen Tihanyban is sokat dolgozott élettani kutatásokkal kapcsolatban és emellett igen járatos volt a nemzetközi szakirodalomban is. Érdekes, hogy bár nem beszélt angolul, de saját erőből nekiállt angolt tanulni és ez által kitúnően értette a szaknyelvet. Jól tudta tehát, hogy ehhez a munkához nagyon felkészült laboratóriumi háttérre van szükség. Egy szó, mint száz: határozottan nemet mondott a VITUKI vezetőségének, amikor felkérték a hőszennyezéssel kapcsolatos laboratóriumi kísérleti munkák irányítására.

Így történt, hogy a még építés alatt álló hidrobiológiai labor vezetését egy radioaktivitást mérő mérnökemberre bízták, aki pedig egy mikrobiológust vett maga mellé a majdani, elsősorban halakkal és egyéb vízi gerinctelenekkel történő hő-tűréses kísérletek végrehajtására. Ebbe az akváriumokkal teli, de - mint a későbbiekben kiderült - komoly kísérleti munkára számos műszaki probléma miatt nehezen átalakítható épületbe került volna az „ellencsapatunk", akikre - később tudtam meg - akkoriban meglehetős ellenszenvvel tekintettek Felföldyék.

Nem volt tehát könnyű beilleszkednem az öregek csapatába. Így találkozhattam először Lajos bátyámmal terepen, a Rakacai- és a Lázbérci-tározókhoz szervezett első kiszállásokon. Ekkor adta kezembe az Ekman-Birge féle markolót: -Te fogod venni az üledékmintákat és a feldolgozott fenékfaunáról majd jelentést írsz nekem. Arra azért vigyázz, hogy le ne nyiszszantsd vele a „micsodádat”! - valahogy így hangzott első bölcs tanácsa. Nos, ilyesmiről az 
egyetemen egy szót sem tanított nekünk senki. A munkáról sem, nemhogy a lenyisszantás kockázatáról. Ez volt tehát a mélyvíz, amelybe kerültem. A Lázbérci-tározó mélysége egyébként a gát előtt pontosan 12 méter volt.

Mely helyszíneken is történtek ezek a kutatások? Elsősorban az észak-magyarországi tározókon. A Rakacai-tározó mentén például hajnali kelés után a parton bóklászva akadtam rá Lajos bátyámmal együtt a Sphaerium corneum nevü borsókagyló-mezőre a sekély vízben, mivel ő is korai kelő volt és tőle tudtam meg ennek a kagylónak a nevét. E tározók mentén rendre felépültek azok a gátőrházak, ahol annak idején elsősorban a főhatósági emberek szállhattak meg. Itt kutathattuk serényen azt a problémát, hogy miért vált anaerobbá a víztér, miközben a szárazföldi vegetációt nem sikerült maradék nélkül eltávolítani a tározótérből. Sajnos a tervezők és a kivitelezők nem mindig hallották meg Lajos bátyám sokszor elhangzott mondását: „A mérnökök azt hiszik, ha valahol van egy gödör tele trutyival és abba vizet eresztenek, abból tározó lesz. Fenét!"

Milyen respektusa volt tudományunknak akkoriban, a valós helyzetben? A hetvenes évek elején - a klasszikus történet szerint - az egyik vízügyi igazgató nem régiben felvett biológusára panaszkodik a másiknak:

- Neked van már biológusod? - kérdezi tőle.

- Igen, van egy, de nem csinál semmit.

- Hogyhogy? - kérdi az előző.

- Hát egész nap csak ül a mikroszkópja mögött.

Sajnos ehhez az is hozzátartozik, hogy számos hidrobiológustól, biológustól a mérnökök csak több oldalas fajlistát kaptak, amit a mérnök nem értett (honnan is értette volna), nem tudott vele mit kezdeni, tehát számára felesleges volt.

Ezt a korszakot hívtuk mérnök-dominálta korszaknak, amely eltartott vagy 25-30 évig, mire - Lajos bátyánk nyomdokaiban - a mérnök szakmával lassacskán sikerült elfogadtatni és érvényre juttatni a biológus szaktudásunk hasznosságát.

\section{Biológiai vízminősítés és a VIZDOK sorozat szakmai hatásai}

A „Biológiai vízminősítés” Felföldy Lajos egyik legsikeresebbnek bizonyult műve. Számos kiadást megért, s a Vízügyi Hidrobiológia sorozat olyan kötete, amely kézikönyvszerűen tartalmazza a felszíni vizek vizsgálatának hagyományos fizikai és kémiai komponensekre vonatkozó teljes analitikai vertikumát. E kémiai összefoglaló konklúziójaként állította össze azt a logikus biológiai szempont-rendszert, amely vizeink hidrobiológiai állapotának egyik sarkalatos módszertani megközelítésévé vált, s a Biológiai vízminősítés-nek lehetett elnevezni. Ebből a könyvből a mérnökök is megérthették, ami addig számukra érthetetlen és felesleges volt. E könyve az idők folyamán számos sorozatbeli társához hasonlatosan a hazai vízminőség-védelmi mérőhálózatban dolgozó hidrobiológus szakembergárda nélkülözhetetlen mindennapi eszközének bizonyult. E fundamentumot tudta tehát letenni az asztalra az az öntörvényű kutató, akit az MTA akkori vezetői Tihanyból elüldöztek, s akinek így tudományos tevékenységéhez a már említett Stelczer Károly vízmérnök tudott megfelelő hátteret biztosítani. Felföldy Lajos neve így méltán forrhatott egybe a biológiai vízminősítés fogalmával.

A sorozat-szerkesztő Felföldy alapos munkájának számos taxonómiai alapmű is terméke lett, a legelső kötetet is ő maga írta a kékalgákról. Alapmű volt ez is, mint a többi. Sok szerző köszönhette személyesen Lajos bátyánknak, hogy kötete végül is összeállt. A mögött a hatalmas írói teljesítmény mögött, amely egy-egy kötet létrejöttéhez szükséges volt, mindenütt ott áll az ő fáradhatatlan személyes szenvedélye is, amivel rendre ostorozta, szinte kikényszerítette a szerzőkből művük megalkotását. Kijelenthetjük nyugodt szívvel, hogy számos könyv nem is készült volna el az ő kifejezett szerkesztői erélye nélkül. 
Közvetlen szemtanúja lehettem e munkájának, amikor épp a „Vízi csigák és kagylók” kötetét szerkesztette. Mély orgánumú hangján mesélte el, hogy amikor kezébe került a határozó első változata, kellőképpen felbosszantva olvasta a legelső kulcsot:

1a A házon héjfedő (operculum) van;

$1 \mathrm{~b}$ A házon héjfedő nincs

- Te! - fordult hozzám - Megírtam nekik, hogy ez mekkora marhaság. Ha találok valahol a vízparton egy Viviparus-héjat, annak természetesen hiányozni fog a „popsifedője” (így nevezte az operculumot). Akkor mi a franckarikát fogok tudni belőle határozni? Éticsigát, nem?

A számos módosító javaslatával átszerkesztett, véglegesnek szánt kéziratot egyik nap ezzel nyomta a kezembe:

- Fogd és használd a mostani Mollusca-határozásaidhoz, utána pedig mondj véleményt róla. - Épp volt egy csomó dolgom e téren, így megpróbálkoztam vele. Csodálatosan sikerült. Kivétel nélkül meg tudtam határozni a fajokat, nem volt semmi hezitálás, bizonytalan lépés a kulcsok használatakor. Mondtam is neki, hogy kitűnően tudtam használni az anyagot. Nos, ezek után le is adta a kéziratot a VIZDOK nyomdába.

Emlékszem rá, hogy annak idején milyen érdeklődéssel hallgatta beszámolómat egy másik csigáról, a Theodoxus fluviatilis-ról, amikor az első példányait megtaláltam a budapesti Duna-szakaszon. Egészen addig ugyanis csak a Tisza-menti három lelőhely-adatról tudtak a malakológusok. Mindig kitűnő szeme volt a faunisztikai/florisztikai újdonságok felfedezéséhez, regisztrálásához. Már réges-rég nyugdíjban volt, de rendszeresen járt ki „botanizálni” ahogy ő nevezte - a Budai-hegységbe, ahol számos növény-ritkaságot talált meg és mesélt nekünk felfedezéseiről a találkozásunkkor. Hihetetlenül széleskörű érdeklődése és fajismerete volt, amelyet ránk is át tudott sugározni.

Így állt tehát össze eggyé hidrobiológus társulatunk a VITUKI-ban Felföldy Lajos irányítása révén.

\section{Analitika, vízkémia, laborálás}

Tőle leshettük el azt a hihetetlen fokú precizitást, amelyet vízkémiai-vízanalitikai laborálása során tanúsított és amellyel egy szélsőségesen végletes mentalitás is együtt járt: minden laboratóriumi technikust és asszisztenst kitiltott laboratóriumából. Még az elhasznált üvegedények mosogatását sem bízta soha az erre a célra alkalmazott mosogatókra, hanem végtelen türelemmel és pontossággal öblítette el többszöri átmosással-öblítéssel lombikjait, pipettáit, miközben egy csepp fölösleges desztillált vizet sem pocsékolt. Eredményei mindig a legmegbízhatóbb kémiai eredmények voltak.

Egyik kedvenc terepi műszere a Yellow Springs Instruments oldott oxigénmérő műszer volt, amelynek rendszeres kalibrálására (0-ra és telített \%-ra egyaránt.) és használatára alaposan betanított. Ezt nem sokkal később meg is örököltem Tőle. Azt hinné a járatlan kutató, hogy műszerrel mérni egyszerű dolog. Nos, erre Lajos bátyám jól megtanított: - Itt lehet a legkönnyebben „elcsúszni”, vagyis: h ü l y e s é g e k e t m é r n i .

Amikor már nélküle jártunk rendszeresen kiszállásokra a Balatonhoz, a Szigetköz vízterei mentén, vagy máshová, igen nagy hasznát vettük korábbi tanításainak. Hasonlóan precíz volt a számos kutatási témája során alapvető fontosságú komponensek, különösen az a-klorofill meghatározásakor. Soha nem maradt el az alapos műszer-kalibrálás, ellenőrzés, nehogy ostoba értékeket kapjon az ember. Sokan manapság erre már jóval kevesebb hangsúlyt fektetnek (tisztelet a kivételnek). 


\section{A nyugdíjba vonulás története: egy igazi Felföldy-sztori}

A VITUKI hidrobiológusainak egyik legfontosabb kutatómunkája a Felföldy Lajos által vezetett Velencei-tó kutatás volt, amely a 70-es évek elején indult. Ekkor - néhány feltáró jellegű kutatáson kívül - még nem sokat tudott erről a szikes tavunkról a hidrobiológus szakma, a tó egészére kiterjedő feltárás ugyanis addig még nem történt. Felföldy Lajos minden évben beszámolt az eredményekről és szép lassan kibontakozott egy hihetetlenül változatos kép a tó eltérő vízminőséggel jellemezhető víztájairól. A feltáró munka rendszeresen folytatódott, és kiterjedt a fito- és a zooplankton együttesek víztér szerinti elemzésére a részletes vízkémiai analízissel együtt. A szürke vizek tája jelentős mértékben különbözött a sötétebb vizektől, a fekete, fenékig átlátszó vizek a tó nyugati felére, a Dinnyési Fertő területére voltak jellemzők, a zöld vizek tája a Fürdető öblözetére korlátozódott, mert ez az öblözet ez az öblözet természetes nádas zárral el volt kerítve a tó többi vízterétől. Ilyen módon sikerült bebizonyítani, hogy a Velencei-tó az előrehaladott természetes feltöltődöttsége ellenére unikális értéket képvisel nemcsak hazai, hanem világviszonylatban is. Erről olyan témabeszámolók születtek, amelyekben Felföldy azt is részletesen kifejtette, hogy mely területek kotorhatók, és mely területeken kell érintetlenül hagyni a nádas zárat annak érdekében, hogy ez a sokszínú vízi világ hosszú távon fennmaradhasson.

De a korszellem akkor is feltartóztathatatlanul múködött: 1980-ra a Közép-Dunántúli Vízügyi Igazgatóság mederkotrói több kiterjedt nádassal egyetemben maradék nélkül kiirtották azt a jó pár kulcsfontosságú nádas határzónát is, amely a Fürdető hipertrófikus (antropogén szennyezés miatt tápanyagokkal túlterhelt) vízterét egészen addig hatékonyan el tudta választani a tó többi vízterületétől. Az indok igen egyszerű volt: a kotrónak éjjel-nappal dolgoznia kellett, hogy minél nagyobb összeget lehessen számlázni a munkáért. Felföldy megírta erről az évről szóló témajelentését, körülbelül ilyen kitételeket megfogalmazásával: a Velencei-tó kezelésével kapcsolatos ostoba mérnöki szűklátókörűség, a technokrata mindent birtokolni akarás, a természetet romboló műszaki barbarizmus, stb. Nem lehet ennél nagyobb mértékű véleménykülönbséget elképzelni műszaki és biológiai szemléletmód között, az biztos. A Főhatóság illetékeseinek természetesen habzott a szája.

- Írassák át vele! - ordította a Főilletékes.

Lajos bátyám válasza erre a következőképp hangzott:

- Marhák. Írja át, akinek nem tetszik, én hozzá nem nyúlok. - azzal elment, pontosan hatvanéves korában, nyugdíjba. Mire Hollandiából hazaértem, augusztus végére, Lajos bácsi már nem dolgozott a VITUKI-ban. Egy világ összeomlott bennem a hírre (Tóth Laci volt végül, aki átírta a jelentést). Lajos bátyám írása „indexre került”: vörös szalagot rögzítettek rá keresztben. Ez jelezte az iromány nem-publikus voltát (valahol őrzöm egy példányát).

\section{Kutatómunka együtt nyugdíjas éveiben}

Szerencsére még sokszor tudtunk együtt dolgozni az Öreggel, aki felhőtlen derűvel jött velünk számos kiszállásra. Ezeken ő is tevékenykedett, szorgalmatoskodott. Egyik ilyen alkalommal a Szigetközben egy általa több évtizede nem látott Senecio-fajjal hozta össze a Jósors az egyik Dunakiliti menti gátoldalban. Megáll az öreg, tisztelettel meghajtja fejét a kicsi növény előtt, majd hatalmas ujjai közé fogja egyik piciny levelét, kézfogást imitálva, s finoman megrázza:

- Jónapot kívánok. Én Felföldy Lajos vagyok. Magával utoljára a .... (sajnos elfelejtettem a helyszín nevét, valamelyik elcsatolt területünk volt, az biztos.) hegyoldalban volt szerencsém találkozni. Hogy van mindig? Isten éltesse itt sokáig. - búcsúzott meghatottan a növénykétől. 
Máskor a Gemenc környéki hullámteret jártam be vele, én az UAZ-t vezettem közvetlenül az árvíz levonulása után, amikor a bajai vízmércén $800 \mathrm{~cm}$-t meghaladó vízállást mértek. Mit mondjak: nehéz terepviszonyok között keveregtünk fel- és alá az ártéri erő iszapjában, de kalandozásunk során egy arcizma sem rándult, nem úgy, mint nekem. Vagy a Kis-Balatonon csónakáztunk rejtelmes öblözetek mentén, arról beszélgetve, hogy kik is ezek az urak, akik teljes mellszélességgel keresztbe tesznek a tározóval kapcsolatos, javító szándékú ötleteinek. De a VITUKI-ban is dolgozott velünk, amikor például lebetonoztunk neki az Akváriumház mögötti területen egy több, alsó és felső vízátáramlásos rekeszből álló kamra-rendszert, amelybe ő változatos vízinövény-fajokból álló mesterséges úszólápot telepített a fél-üzemi tápanyag-eltávolításos kísérletsorozatához. Tevékenyen közremúködött számos kutatási feladatunk során, nagyon jó volt vele dolgozni.

Lajos bátyám elsősorban botanikus volt, Soó-tanítvány, a növények nagy ismerője, a növény-társulástan egyik hazai tudós kutatója. Elképesztően nagy fontosságot tulajdonított egész életében a Herbáriumnak, a növények gyüjtésének, szerette nagyon az ezzel együtt járó részletes bíbelődést, a Scientia amabilis, a szeretetre méltó tudomány hite szerint nem sokat ért dokumentatív herbárium-készítés nélkül. Ennek akkor adott hangot a mi fülünk hallatára is, amikor nyugdíjasként a Kis-Balaton újonnan létesített tározótereinek ökológiai problémáit vette szemügyre. Erre 1985 után került sor, amikor az első tározóteret feltöltötték és megkezdték kialakítani a víztereket.

Lajos bátyánk mindjárt a terület feltöltésekor határozott véleményt fogalmazott meg a létesítménnyel kapcsolatban: Hiányzik a beeresztő mütárgy vagy zsilip. Emiatt nincs teljes vízkormányzási lehetőség, mivel a tározóba kerülő vízmennyiség szabályozhatatlan. Innentől kezdve problémákat jósolt a későbbi üzemeltetéssel kapcsolatban. (Megjegyzem, hogy angol vízi makrofiton-specialista barátom, Nigel Holmes ugyanerre a következtetésre jutott, mikor részletesen bejártam vele ugyanezt a vízterületet.). Ellenezte a vízi makrofiton együttes kitermelését a tározóból, mint egy hatékonynak gondolt tápanyag-eltávolítási beavatkozást, mert ezzel ellentétben csak abban látott fantáziát, ha sűrűn benövényesedik az új Kis-Balaton (gyökérzónás tápanyag eltávolítás), a Hídvégi-tó (ő nevezte el e vízteret így, a mérnöki szemléletű $I$. ütem helyett.). Jellemző a kor szemléletére, amikor lezárták a Kis-Balaton alsó részénél a Zalát, a Balatonból a halak felúsztak ezen a szakaszon, a pangó, oxigénhiányos vízben elpusztultak, az autósok gyönyörködhettek ebben. Amikor az építést felügyelő VIZIG főmérnökének ezt tudtára adták és javasolták, hogy egy kis vízutánpótlással, egy cső átvezetésével szüntesse meg ezt a távolról sem esztétikus látványt, a válasza az volt: - Ne nevettesd ki magad. Az elpusztult halak értéke a beruházás összegének hány tízezrede?

Sikertelen küzdelmet vívott az általa javasolt nádas-telepítéssel kapcsolatban a területet üzemeltető VIZIG illetékeseivel, akik végül is kimondták a verdiktet: ameddig mi leszünk a terület gazdái, itt egy szál nádat sem fogtok telepíteni... Pedig fiatal kolléganőjével, a szintén tavaly, tragikus hirtelenséggel eltávozott Mándoki Mónikával igen sikeres nádtelepítési kísérleteik voltak már (gyökérzónás növényi tápanyag eltávolítás), amelynek a területen való adaptálása nagyon egyszerű dolog lett volna. Ezen időszak terület-bejárásai alkalmával Lajos bátyánk szakmai útmutatásai alapján Mónika kitűnő herbáriumi anyagot gyűjtött össze.

A Kis-Balaton végül nem lehetett nádas tó. Algás tó lett belőle, a hivatalos vélemények szerint ugyanis ezzel - a gyakori, télen is előforduló kékeszöld alga-vízvirágzásokkal tarkított - üzemrenddel lehetett optimalizálni a tározóban a tápanyag-eltávolítás folyamatát... Emlékezzünk rá: Felföldy Lajos foszfin-teóriája szerint épp az ellenkezőjére lett volna szükség: anaerob viszonyokat létrehozni a sűrü makrofiton-állomány gyökérzónájában. A meddő mérnök-biológus vita kísértetiesen hasonlított az egykori, Velencei-tavi fiaskóhoz...

Egy másik, gyökérzónás növényi tápanyag-eltávolítással kapcsolatos megbízása keretében több nyáron át Badacsonytomaj térségében folytatott részletes helyszíni vizsgálatokat egy lápi mintaterületen, ahol laboratóriumi mérések során vizsgálta a be- és kifolyó víz fon- 
tosabb tápanyag-komponenseit. Itt is rendkívül precíz módon dolgozott, valahogy azonban nem jött ki megfelelőképpen az anyagmérleg.

Mérési hiba? Laboratóriumi pontatlanság? Nagyon bosszantotta a dolog és megkérte idős mérnök kollégáját, Muszkalay Lászlót, hogy jöjjön már el hozzá és mérjen neki rendes vízhozamot a be- és kifolyó műtárgyakon. Nem volt könnyű eredményre jutniuk. Ha valaki nem ismerte volna őket, azzal gyanúsította volna meg a két idős Mestert, hogy csak „szarakodnak", húzzák az időt. Ezzel szemben Muszkalay türelmes és fáradtságot nem ismerő munkával rájött, hogy a kieresztő mútárgy csatorna-síkjában - rossz kivitelezés következtében van egy enyhe törés, emiatt adódik diszkrepancia Lajos bácsi anyagmérleg-számításánál. Nagy volt mindkettőjük boldogsága, hogy sikerült tisztázniuk a problémát. Soha nem fogjuk elfelejteni, mekkora örömmel újságolta Lajos bátyánk a történetet.

Meg kell emlékeznem végül arról is, hogy Lajos bátyám tanácsára rövid idő alatt a halakkal kapcsolatos kutatásoktól a vízi makrogerinctelenek felé fordultam. Abban az időben, amikor ezt felvetette, számos olyan feladatunk kezdett kibontakozni, amelyek ezt az irányvonalat kifejezetten igényelték volna. Miután alaposabban kezdtem ezzel az élőlényegyüttessel foglalkozni, engem is arra buzdított, hogy írjak egy határozó-kötetet a gerinctelenek családjaival kapcsolatban. Erre akkor még nem került sor (csak később írtam ugyan egy ilyen anyagot, de nem a sorozat számára, hanem csak házi használatra). Ha meggondolom, Felföldy Lajos útmutatásai végül is szélesebb körben hatottak, mint akkor gondoltam, hiszen a vízminőségi mérőhálózati rutinfeladatok közé ennek a szakmai váltásnak a következtében lehetett azután 2002-ben bevezetni - a környező országokhoz képest így is jócskán lemaradva - a makrozoobenton monitoringot Magyarországon.

Lajos bátyám a nyolcvanas évek vége felé agyvérzésen ment keresztül, a rövid ideig tartó részleges lebénulásból sikerült kiverekednie magát. Nagyon örültünk e „kaland” szerencsés kimenetelének. Sose felejtem el viszont, hogy egyszer, nem sokkal ezt követően egy biológus kolléga a Vele való találkozáskor sopánkodva köszöntötte: „- Szervus Lajos bátyám. Hallom beteg voltál nemrég.” Mire Ő: „- Én? Beteg? Egy fenét. Egyszerűen csak megütött a guta. Az nem betegség..." Méltatlankodva mesélte, hogy a betegség és a gutaütés két különböző jellege az emberi egzisztenciának. Márpedig neki nem betegsége volt, „csak” gutaütése.

Nem volt puha legény Lajos bátyánk soha.

\section{Kalandok a Kék Villámmal}

Lajos bácsi autója. Kék Villámnak hívta, sötétkék bogárhátú kis Volkswagen, kitűnő állapotú fényesen ragyogó jószág. Másik neve Icike, nyilván a picike szóból származtatván...

Még az aktív VITUKI-s években történt, hogy levitt bennünket a Bajai Hidrobiológus Napokra. Az 51-úton igyekeztünk lefelé, amikor Ráckeve után valahol előz és hirtelen egy keresztbe csíkos, felfestett „Járműforgalom elől elzárt terület” közepén találjuk magunkat. Bosszús hangon dörmögi: - Honnan a fenéből vagyok köteles tudni, hogy pont ilyen szakaszra érkezek meg előzés közben? - Eltelik pár pillanat és elhagyunk egy „Előzni tilos” feloldó táblát (is). - Jaaaa. Az elejét nem láttam. - Volt ilyen, elnézte.

Az 51-es úton vannak kanyarok szép számmal, volt forgalom is, pláne teherautók jártak rajta sűrűn, így Lajos bátyánk rá volt kényszerítve a tempós menetre és a gyakori előzésekre. A Kék Villám anyósülésén Gulyás Pali, hátul meg Fleit Ernővel mi ültünk ketten. Egyik előzésnél jött velünk szembe egy nagy ZIL. Szorítottuk is egymás térdét Ernővel izgatottan, hogy mi lesz ebből. Lajos bácsi komótosan próbálkozott a gázpedállal, a megterhelt Kék Villám lustán vette fel a fordulatot. A teherautó nagyon közel volt már. Ekkor szelíden megszólalt: Szedd a lábad, Icike. - noszogatta kisautóját mosolyogva az Öreg és tessék: csoda történt. Sikerült visszaslisszolnunk a helyünkre. Markunk szorítása enyhült, Gulyás is letörölte a verejtékét, Lajos bácsi megjegyezte: - Mi van? Beszartatok? Nem bíztatok a Kék Villámban? 
Nem emlékszem a pontos dátumra, hogy mikor fejezte be Lajos bátyám a vezetést, csak az azt kiváltó eseményre. Talán szintén előzéses történet és mintha teherautós is lett volna egyben... És talán a Ferihegyi gyorsforgalmi úton esett meg? A tetejére borult autó az aszfalton való csúszása közben lassan veszít eredeti sebességéből. A történet további részát a következőképpen hallottam az Öreg szájából:

- Azt gondoltam, hogy itt van a vége a világnak: recsegés-karistolás-ropogás, valahova száguldok, de biztos már a másvilágon. No, ennyi volt, fura dolog így fejjel lefelé, fordított világban ülni, mondom magamban. Egyszer csak a nagy zaj elül, lenyugszik minden. Én meg arra leszek figyelmes, hogy plümm-plümm-plümm, valami finom ütemben dorombol. De hiszen ez Icike motorhangja. De hát akkor viszont én élek. Jé, ez meg itt lifeg előttem, kis fényesség: a slusszkulcs. Elfordítom, kikapcsolom a motort, valahogyan kievickélek a járgányból és mondom magamnak: -Ennyi volt, Lajos, jobb lesz végképp letenni az autót így vénségedre.

\section{A növénytári munka}

Lajos bátyám akkor talált magára igazán, amikor elkezdett bejárni a Növénytárba. Ki tudott teljesedni benne a botanika iránti szeretet. Eközben nálunk is gyakorta megjelent és részletesen beszámolt sziszifuszi munkájáról: a herbáriumi lapok revízióját végezte önként. Ez a munka olyan, amelyet nem sokan tudnának felvállalni, különösen a fiatalabb generációból lenne nehéz vállalkozót találni rá. Lajosnak a munka nem okozott nehézséget, hiszen szívéhez olyan közel álló tevékenység, amelynek során teljességgel át tudta élni a gyűjtés minden fázisát a legeslegvégső állomásig, a NÖVÉNY megnyugtató, helyes besorolásig. Elmondása szerint bőven volt tennivalója. Sok-sok lapot átnézett, számos tévedésre rájött és ezeket mind sikerült is kijavítania. Soha nem fogjuk tudni felmérni, hogy mekkora volumenű tudományos munkát köszönhetünk neki.

\section{A legutolsó találkozás}

Mintegy négy évvel ezelőtt, telefonon történt bejelentkezést követően egy délután felmentünk Szekeres Joci kollégámmal Lajos bátyámhoz Váci utcai harmadik emeleti lakására beszélgetni, meg amiatt is, hogy egyáltalán: fiatal kollégám is megismerhesse az idős Mestert. Csengettünk, az ajtó nyílik, s ott áll a küszöbön, kopaszon. Megkérdeztem, honnan ez a fura új frizura, Lajos bátyám? Azt válaszolta: - Tudod, egyszer csak belenéztem a tükörbe és láttam ám, hogy elkezdett ritkulni a hajam. No, mondom az Úristennek, lássuk csak Uram, mire megyünk mi ketten, így együtt. És lenyírtam a maradék hajamat... Hát azóta.

Kérdeztem Lajos bácsit, hiányzik-e neki a hidrobiológusi szakmai tevékenység? Mosolyogva válaszolt: - Ugyan, miért hiányozna? Mindenre emlékszem, jó volt, de most mást csinálok. Más a dolgom. Minden nap legalább egyszer lemegyek az utcára és vásárolok, sétálok. Erre nagyon nagy szükségem van, mert ha egyszer is elkezdenék lustálkodni, akkor végem lenne.

Nekem ajándékozta két angol nyelvű szakmai könyvét és egy fiolányi Theodoxus fluviatilis héjat is, amelyeket ô gyűjtött a Duna-parton, sétája közben, megmaradván a természet csendes szemlélőjének. Ekkor volt 92 éves. Sajnos ezután már nem mentem fel hozzá többé.

\section{Tanítványok}

Szűkebb értelemben vett tanítványa nemigen volt. Aki témavezetőjéül választotta őt, annak vért kellett izzadnia, hiszen Felföldy Lajos maximális munkát követelt meg a delikvenstől. Kegyetlen szókimondásával sokszor sikerült elrettentenie a megkritizált embert, akinek 
pedig - sértődés helyett - ezt a kritikát el kellett volna viselnie és meg kellett volna fogadnia minden egyes szavát.

Tanítványai azonban - általános értelemben - nagy számban voltak, hiszen rendszeresen visszajárt Debrecenbe hidrobiológiára oktatni az egyetemi ifjúságot. Ezek az előadások azután mindnyájunkban örökre bennünk maradtak. Az Öreg, aki nemhiába gondolkodott annak idején a színészi pálya választása mellett, magabiztosan fellépő, lenyűgöző stílusú, kimagasló szellemi műveltségű kutatóként meggyőzően volt képes elementáris hatással lenni hallgatóira, elsősorban a fiatalságra.

\section{Az életmü}

Ki volt Ő? Olyan szakember, aki - közhelynek tűnik, de igaz - eleven elméjével az elméleti tudományt képes volt ötvözni a gyakorlattal. Akadémiai kutatóintézetből került a vízügyi kutatások élére. Bármilyen tudományos problémával hozzá lehetett fordulni, ő megtalálta a választ, biztos irányt tudott mutatni. Tudása emiatt pótolhatatlan, mert komplex elméjű kutató lévén sok dolgot képes volt átlátni és képes volt szintetizálni. Sajnos a jelen kor szemléletében csak az fontos, amelyik rövid távon hasznot hoz.

A vízügyi kutatómunka és az akadémiai kutatások között választóvonal van. A vízügyi kutatások- többek között a VITUKI megszüntetésével - különösen mostoha sorsra jutottak, jó szerével meg is szűntek. Ma nem könnyebb a helyzet: közvetlenül tapasztaljuk, hogy az ún. Magasságos Tudomány sok esetben hajlamos lenézni a gyakorlati kutatómunkát, a tudományosságot unszoló/erőltető világ nagyzolása az elméleti tudást részesíti előnyben, így a gyakorlat - amelyet nem impakt-faktorral mérnek (szerencsére) - megszenvedi a szélsőségesen polarizált, financiálisan átgondolatlan részrehajlást. Ez tragikus, mert pontosan azok a gyakorlatban jelentkező környezeti problémák nem kerülhetnek megnyugtató megoldásra, juthatnak mostoha sorsra, amelyekhez a tudomány teljes fegyverzetére, valamint a megfontolt fiskális szemléletre egyaránt szükség lenne. Mind a mai napig csupán részeredményekkel lehet „büszkélkednünk” a Szigetköz, a Kis-Balaton, a folyami nagymeder-szabályozás, az árvizek elleni védekezés, vagy akár a természetvédelem-agrárium antagonisztikus párviadalával kapcsolatos szakkérdések megoldása során. Pedig a speciális és a holisztikus szemléletű tudomány, valamint ezek elméleti és a gyakorlati vonatkozásai egyaránt szükségesek lennének komplex problémáink megközelítéséhez.

Felföldy Lajosra emlékezünk, és látjuk, hogy eltávozásával, ezzel együtt közeli s távoli múltunk számos szellemi nagyságának elmenetelével olyan elméket veszítettünk, veszítünk, akiknek szellemi terrénuma, kulturáltsága jóval felülmúlta a jelenkori átlagét. Az, hogy a résztudományok által specializálódott világunkban már nemigen találhatók ilyen személyiségek, kimondhatatlanul nagy problémát jelent, s alkalmasint akár rettegést is kiválthatna belőlünk tudván, hogy micsoda kaotikus jövőkép merül fel mai nemtörődöm, mértéktelen, túlfogyasztó, rossz értelemben ember-centrikus világunkban. Ezeknek a széles látókörű, a humán tudományokban is jártas, ún. polihisztor-típusú kutató elméknek a pótlására jelenlegi oktatási rendszerünk alkalmatlan. Én a polihisztor jelzőt pontosan annak az embernek a megjelölésére használom, aki literátus és egyben művész lelkületű, művelt irodalmár és író, valamint a természettudományos szemlélete, gondolkodásmódja is magasan az átlag fölötti, emiatt pedig képes megfelelő alázattal és kellő felelőséggel szemlélni világát. E kritériumoknak szerintem Felföldy Lajos maradéktalanul megfelel. Nem csoda, hogy minden vele töltött perc, minden beszélgetés feledhetetlen és felbecsülhetetlen értékű volt számunkra.

Ezért emlékezzünk illő tisztelettel Nagy Elődeinkre. Ennek egyik szép, példáját mutatja a tanítványok múltat idéző visszapillantása a Tilia VIII. kötetében: a Mesterek előtti méltó meghajlást. 
Felföldy Lajost nem érdekelte, ha a „nagybecsű Akadémia” - ahogy nevezte - mellőzi. Mosolyogva vette tudomásul, ha a kor nem méltányolta eléggé tudását (végül az Állami-, majd a Széchenyi Díjat sem kapta meg), hiszen a tudás biztos talaján állt. Lajos bátyánk kivételes ember volt. Rá és életművére egyaránt tisztelettel emlékezünk.

\section{Hamvak a Tóban}

2016 őszén hallottam, hallottuk a szomorú hírt. Elment. Életének utolsó rövid szakaszát szeretett felesége halála után egy Idősotthonba való költözéssel fordította a végleges és visszavonhatatlan irányba. Sajnálom, hogy sehogy nem akadtam az Idősotthon nyomára azon a néhány temetésen, amelyeken egykori VITUKI-s kollégákat kísértünk utolsó útjukra. Sajnos jó néhány ilyen alkalom adódott mostanság.

Az egyetlen vigasztaló hír, amit szintén elhozott hozzánk a szél, hogy családja végakaratának megfelelően hamvait a Balatonba szórta. Igen, vigasztaló hír. Hiszen Felföldy Lajos ott van, ahol a helye van. A szeretett tó fogadta be... A mi szeretetünk és emlékezésünk szintén.

Beérkezett: 2017. 02. 08. • Elfogadva: 2017. 03. 01. 